OPEN ACCESS

Citation: Hasan Genç, Bekir Yildirim, Mikail Açar, Tolga Çetin (2021) Statistical evaluation of chromosomes of some Lathyrus L. taxa from Turkey. Caryologia 74(3): 107-117. doi: 10.36253/caryologia-1124

Received: November 01, 2020

Accepted: March 29, 2021

Published: December 21, 2021

Copyright: @ 2021 Hasan Genç, Bekir Yildirim, Mikail Açar, Tolga Çetin. This is an open access, peer-reviewed article published by Firenze University Press (http://www.fupress.com/caryologia) and distributed under the terms of the Creative Commons Attribution License, which permits unrestricted use, distribution, and reproduction in any medium, provided the original author and source are credited.

Data Availability Statement: All relevant data are within the paper and its Supporting Information files.

Competing Interests: The Author(s) declare(s) no conflict of interest.

\section{Statistical evaluation of chromosomes of some Lathyrus L. taxa from Turkey}

\author{
Hasan Genç ${ }^{1}$, Bekir Yildirim ${ }^{2, *}$, Mikail AçAR ${ }^{3}$, Tolga Çetin ${ }^{4}$ \\ ${ }^{1}$ Department of Science Education, Faculty of Education, Burdur Mehmet Akif Ersoy Uni- \\ versity, Burdur, 15100, Turkey \\ ${ }^{2}$ Department of Plant and Animal Production, Burdur Food, Agriculture and Livestock \\ Vocational School of Higher Education, Burdur Mehmet Akif Ersoy University, Burdur, \\ 15100, Turkey \\ ${ }^{3}$ Department of Plant and Animal Production, Tunceli Vocational School of Higher Edu- \\ cation, Munzur University, Tunceli, 62000, Turkey \\ ${ }^{4}$ Science Teacher, Republic of Turkey Ministry of National Education, Seydikemer, Muğla, \\ 48850, Turkey \\ ${ }^{\star}$ Corresponding author. E-mail: bytr33@yahoo.com
}

\begin{abstract}
In this study, a statistical analysis was performed on mitotic metaphase chromosomes of 26 Lathyrus taxa, four of which are endemic. ANOVA, correlation analysis, PCA and cluster analysis were performed to determine the relationships between taxa based on chromosomal criteria. The morphological similarities of plant taxa and chromosomal statistics results may not be always parallel to each other. According to the findings obtained as a result of analysis, the following taxa, which are close to each other were determined: L. hirsutus - L. odoratus, L. brachypterus var. haussknechtii - L. phaselitanus, L. stenophyllus - L. chloranthus, L. gorgoni var. gorgoni - L. nissolia - L. pratensis, L. tuberosus - L. annuus.
\end{abstract}

Keywords: Lathyrus, chromosome, endemic, statistical analysis, Turkey.

\section{INTRODUCTION}

Lathyrus L., a genus belonging to Fabaceae family consisting of more than 200 taxa is distributed almost all over the World (Allkin et al. 1986). The main diversity centers of Lathyrus are the Mediterranean region, Asia Minor and North America, as well as temperate South America and East Africa (Klamt \& Schifino-Wittmann 2000). In Flora Europaea, 54 species of Lathyrus were reported from different areas of Europe (Tutin et al. 1968). Lathyrus is represented by 79 taxa in Turkey, 25 of which are endemic to Turkey (Davis 1970; Davis et al. 1988; Güner et al. 2000; Genç \& Şahin 2008; Genç 2009; Genç \& Şahin 2011).

Some agriculturally important species of the genus Lathyrus are grown for use as forage or human food (Yamamoto et al. 1984; Genç \& Şahin 2001). Seeds of some Lathyrus species are used in the preparation of regional human food in different countries in the world (Kumar 1997; Uncuer et al. 2016). 
A lot of studies such as taxonomical, cytotaxonomical, morphological, anatomical, etc. have been carried out on Lathyrus taxa which are so important in terms of agriculture. Caryological studies were conducted on $L$. saxatilis (Vent.) Vis., L. vinealis Boiss. \& Noe, L. inconspicuus L., L. setifolius L. (Şahin \& Altan 1990) and L. rotundifolius Willd. subsp. miniatus (Bieb. ex Stev.) Davis, L. cassius Boiss., L. cicera L., L. aphaca L. var. modestus P.H. Davis (Şahin 1993). Anatomical, morphological and palynological features of $L$. inconspicuus, L. vinealis from Orobastrum (Taub.) Boiss. section and L. sativus L., L. hirsutus L. from Cicercula (Medic.) Gren. \& Godr. section were investigated qualitatively and quantitatively (Mantar et al. 2002; 2003). There are also studies conducted on the cytotaxonomical properties of L. brachypterus Čel. var. haussknechtii (Širj.) Davis, L. spathulatus Čel., L. ochrus (L.) DC., L. odoratus L., L. belinensis N. Maxted \& D. J. Goyder, L. clymenum L., L. phaselitanus Hub-Mor. \& Davis and the morphological characteristics of grass pea (L. sativus) (Genç et al. 2009; Grela et al. 2010). A numerical taxonomic study on 54 of 58 Lathyrus taxa in Flora of Turkey was conducted (Doğan et al. 1992).

This study was carried out using the statistical evaluation of the findings of previous cytotaxonomical studies conducted by us (Şahin et al. 1998; Şahin et al. 2000; Genç \& Şahin 2001; Genç et al. 2009).

In this study, by applying statistical analysis to the metaphase chromosome organization, it is aimed to see whether the taxa with the same chromosome morphology are similar taxonomically or not.

\section{MATERIAL AND METHODS}

\section{Material}

Plant specimens and seeds belonging to Lathyrus taxa were collected from natural habitats in Turkey during 1995-2007. Some plant specimens were stored at personal herbarium of Genç, while other herbarium specimens were stored at the FUH (Furat University, Elazı̆g, Turkey) and GUL (Süleyman Demirel University, Isparta, Turkey) herbariums.

The eight sections of 28 investigated taxa according to morphological classification in Davis 1970 and Güner et al. 2000 are given in Table 1 .

\section{Methods}

\section{Chromosome measurements}

Determination of chromosome number and karyotype analyses of taxa were performed at mitotic metaphases.
Table 1. The sections of the investigated Lathyrus taxa.

\begin{tabular}{|c|c|}
\hline Section & Taxa \\
\hline Platystylis & $\begin{array}{l}\text { L. brachypterus var. haussknechtii, L. digitatus (Bieb.) } \\
\text { Fiori, L. spathulatus }\end{array}$ \\
\hline Pratensis & $\begin{array}{l}\text { L. pratensis L., L. laxiflorus (Desf.) O. Kuntze subsp. } \\
\text { laxiflorus }\end{array}$ \\
\hline Lathyrus & $\begin{array}{l}\text { L. tuberosus L., L. belinensis, L. odoratus }[\text { L. odoratus } \\
\text { is cultivated as an ornamental plant in Turkey (Davis } \\
\text { 1970)] }\end{array}$ \\
\hline Orobastrum & $\begin{array}{l}\text { L. sphaericus Retz., L. inconspicuus, L. tauricola P. H. } \\
\text { Davis, L. setifolius }\end{array}$ \\
\hline Cicercula & $\begin{array}{l}\text { L. annuus L., L. gorgoni Parl. var. gorgoni, L. cicera, L. } \\
\text { sativus, L. stenophyllus Boiss. \& Heldr., L. phaselitanus, } \\
\text { L. hirsutus, L. chloranthus Boiss. }\end{array}$ \\
\hline Clymenum 1 & L. clymenum, L. ochrus \\
\hline Nissolia & L. nissolia L. \\
\hline Aphaca & $\begin{array}{l}\text { L. aphaca var. affinis (Guss.) Arc, L. aphaca var. } \\
\text { pseudoaphaca (Boiss.) Davis, L. aphaca var. modestus }\end{array}$ \\
\hline
\end{tabular}

The seeds were germinated at room temperature in petri dishes covered with cotton. When the root tips reached 1 $\mathrm{cm}$ in length, they were cut off and pretreated with saturated paradichlorobenzene solution for 4 hours. At the end of the pretreatment process, root tips were washed and fixed with acetic acid-ethyl alcohol $(1 / 3 \mathrm{v} / \mathrm{v})$ for 24 hours. Then, the root tips were washed again and stored in $70 \%$ ethyl alcohol at $2-4{ }^{\circ} \mathrm{C}$ (Sharma \& Gupta 1982).

After washed root tips had been hydrolyzed in $1 \mathrm{~N}$ $\mathrm{HCl}$ for $10-15 \mathrm{~min}$ at $60^{\circ} \mathrm{C}$. Feulgen method was used in the dyeing process (Elçi 1982; Sharma \& Gupta 1982). Squashed preparats were prepared using root tips. The karyotypes were discussed according to Levan et al. (1964). Chromosomes measurements of Lathyrus taxa are given in Table 2.

\section{Data analyses}

For the analysis of karyotype characteristics, the following methods and formulas were used. The measurements were performed on haploid data sets. The following traits in each karyotype were measured: TLC (total length of chromosomes), MTLC (mean of total length of chromosomes), MAX (maximum length of chromosome), MIN (minimum length of chromosomes), MLA (mean of long arms), MSA (mean of short arms), MrV (mean of $r$ value), MdV (mean of $d$ value), MAR (mean of arm ratio), MCI (mean of chromosome index), MRLC (mean of relative length of chromosomes), DRL (difference of range of relative length), TF\% (total form percentage), S\% (relative length of shortest chromosome), A1 (intrachromosomal asymmetry index), A2 (inter- 
Table 2. Chromosomes measurements of Lathyrus taxa (Ch. No: Chromosome No, C: Total length of the chromosome, L: Length of the long arm, S: Length of the short arm, Sat.: Satellite).

\begin{tabular}{|c|c|c|c|c|c|c|c|c|c|c|c|c|c|c|c|c|c|c|c|}
\hline $\begin{array}{l}\text { Ch. } \\
\text { No }\end{array}$ & $\mathrm{C}$ & $\mathrm{L}$ & $S$ & Sat. & $\begin{array}{l}\text { Ch. } \\
\text { No }\end{array}$ & $\mathrm{C}$ & $\mathrm{L}$ & S & Sat. & $\begin{array}{l}\text { Ch. } \\
\text { No }\end{array}$ & $\mathrm{C}$ & $\mathrm{L}$ & S & Sat. & $\begin{array}{l}\text { Ch. } \\
\text { No }\end{array}$ & $\mathrm{C}$ & $\mathrm{L}$ & S & Sat. \\
\hline \multirow{2}{*}{\multicolumn{5}{|c|}{$\begin{array}{l}\text { L. brachypterus var. } \\
\text { haussknechtii }\end{array}$}} & \multirow{2}{*}{\multicolumn{5}{|c|}{ L. digitatus }} & 5 & 5.68 & 3.68 & 2.00 & & 5 & 4.18 & 2.23 & 1.55 & \\
\hline & & & & & & & & & & 6 & 5.43 & 3.45 & 1.94 & & 6 & 3.81 & 2.23 & 1.58 & \\
\hline 1 & 6.48 & 3.64 & 2.84 & & 1 & 9.16 & 4.88 & 4.28 & & 7 & 4.77 & 2.74 & 2.03 & & 7 & 3.30 & 2.04 & 1.26 & \\
\hline 2 & 6.29 & 2.86 & 2.06 & 1.37 & 2 & 7.73 & 4.43 & 3.30 & & \multicolumn{5}{|c|}{ L. sativus } & \multicolumn{5}{|c|}{ L. stenophyllus } \\
\hline 3 & 5.32 & 3.16 & 2.16 & & 3 & 7.21 & 4.12 & 3.09 & & 1 & 6.21 & 3.74 & 2.47 & & 1 & 7.16 & 4.21 & 2.95 & \\
\hline 4 & 5.10 & 2.96 & 2.14 & & 4 & 6.85 & 3.99 & 2.86 & & 2 & 5.85 & 2.49 & 1.96 & 1.40 & 2 & 6.31 & 4.15 & 2.16 & \\
\hline 5 & 4.78 & 2.79 & 1.99 & & 5 & 6.78 & 4.18 & 2.60 & & 3 & 5.53 & 3.34 & 2.19 & & 3 & 5.90 & 3.75 & 2.15 & \\
\hline 6 & 4.64 & 2.91 & 1.73 & & 6 & 6.37 & 3.82 & 2.55 & & 4 & 5.36 & 3.44 & 1.92 & & 4 & 5.38 & 3.46 & 2.12 & \\
\hline 7 & 4.32 & 2.70 & 1.62 & & 7 & 6.03 & 3.66 & 2.37 & & 5 & 5.11 & 3.31 & 1.80 & & 5 & 5.25 & 3.24 & 2.01 & \\
\hline \multicolumn{5}{|c|}{ L. spathulatus } & \multicolumn{5}{|c|}{ L. pratensis } & 6 & 4.87 & 3.29 & 1.58 & & 6 & 4.90 & 2.86 & 2.04 & \\
\hline 1 & 8.00 & 4.39 & 3.61 & & 1 & 7.62 & 3.53 & 2.77 & 1.32 & 7 & 4.47 & 2.71 & 1.76 & & 7 & 4.65 & 2.64 & 2.01 & \\
\hline 2 & 7.22 & 3.56 & 2.46 & 1.20 & 2 & 6.19 & 3.91 & 2.28 & & \multicolumn{5}{|c|}{ L. phaselitanus } & \multicolumn{5}{|c|}{ L. hirsutus } \\
\hline 3 & 6.42 & 3.97 & 2.45 & & 3 & 5.99 & 3.94 & 2.05 & & 1 & 6.41 & 3.64 & 2.77 & & 1 & 8.36 & 4.78 & 3.58 & \\
\hline 4 & 6.11 & 3.71 & 2.40 & & 4 & 5.61 & 3.64 & 1.97 & & 2 & 5.43 & 2.24 & 1.90 & 1.29 & 2 & 7.08 & 4.93 & 2.15 & \\
\hline 5 & 5.76 & 3.43 & 2.33 & & 5 & 5.36 & 3.45 & 1.91 & & 3 & 5.33 & 3.29 & 2.04 & & 3 & 6.53 & 4.52 & 2.01 & \\
\hline 6 & 5.50 & 3.18 & 2. 32 & & 6 & 4.99 & 3.18 & 1.81 & & 4 & 5.16 & 3.26 & 1.90 & & 4 & 6.30 & 4.15 & 2.15 & \\
\hline 7 & 5.09 & 2.95 & 2.14 & & 7 & 4.65 & 2.77 & 1.88 & & 5 & 4.85 & 2.85 & 2.00 & & 5 & 5.93 & 4.01 & 1.92 & \\
\hline \multicolumn{5}{|c|}{ L. laxiflorus subsp. laxiflorus } & \multicolumn{5}{|c|}{ L. tuberosus } & 6 & 4.73 & 2.83 & 1.90 & & 6 & 5.48 & 3.55 & 1.93 & \\
\hline 1 & 9.27 & 5.33 & 3.94 & & 1 & 8.10 & 3.76 & 2.86 & 1.48 & 7 & 4.36 & 2.65 & 1.71 & & 7 & 5.07 & 2.89 & 2.18 & \\
\hline 2 & 8.48 & 4.93 & 2.49 & 1.06 & 2 & 6.51 & 4.15 & 2.36 & & \multicolumn{5}{|c|}{ L. chloranthus } & \multicolumn{5}{|c|}{ L. clymenum } \\
\hline 3 & 8.15 & 5.24 & 2.91 & & 3 & 6.27 & 4.18 & 2.09 & & 1 & 7.35 & 4.12 & 3.23 & & 1 & 7.22 & 3.68 & 2.13 & 1.41 \\
\hline 4 & 7.83 & 5.30 & 2.53 & & 4 & 5.95 & 3.76 & 2.19 & & 2 & 6.56 & 3.67 & 2.89 & & 2 & 6.62 & 4.72 & 1.90 & \\
\hline 5 & 7.43 & 4.89 & 2.54 & & 5 & 5.77 & 3.77 & 2.00 & & 3 & 5.94 & 3.77 & 2.17 & & 3 & 5.76 & 4.06 & 1.70 & \\
\hline 6 & 7.04 & 4.78 & 2.26 & & 6 & 5.53 & 3.47 & 2.06 & & 4 & 5.65 & 3.54 & 2.11 & & 4 & 5.36 & 3.18 & 2.18 & \\
\hline 7 & 6.32 & 3.54 & 2.78 & & 7 & 5.01 & 3.11 & 1.90 & & 5 & 5.34 & 3.46 & 1.88 & & 5 & 4.13 & 2.93 & 1.20 & \\
\hline & & beliner & nsis & & & & phaer & icus & & 6 & 4.99 & 3.07 & 1.92 & & 6 & 3.40 & 2.03 & 1.37 & \\
\hline 1 & 6.56 & 3.70 & 2.86 & & 1 & 6.92 & 3.83 & 3.09 & & 7 & 4.70 & 2.90 & 1.80 & & 7 & 2.83 & 1.80 & 1.03 & \\
\hline 2 & 5.88 & 3.47 & 2.41 & & 2 & 6.31 & 3.64 & 2.67 & & & & ochr & & & & & nisso & & \\
\hline 3 & 5.20 & 3.18 & 2.02 & & 3 & 5.84 & 3.49 & 2.35 & & 1 & 6.00 & 2.58 & 2.05 & 1.37 & 1 & 6.86 & 2.74 & 2.45 & 1.67 \\
\hline 4 & 4.95 & 3.11 & 1.84 & & 4 & 5.51 & 3.49 & 2.02 & & 2 & 5.55 & 3.72 & 1.83 & & 2 & 6.56 & 4.20 & 2.36 & \\
\hline 5 & 4.81 & 3.06 & 1.75 & & 5 & 5.27 & 3.22 & 2.05 & & 3 & 5.26 & 3.74 & 1.52 & & 3 & 5.89 & 3.87 & 2.02 & \\
\hline 6 & 4.64 & 2.76 & 1.88 & & 6 & 5.08 & 3.18 & 1.90 & & 4 & 5.02 & 3.32 & 1.70 & & 4 & 5.58 & 3.46 & 2.12 & \\
\hline 7 & 4.48 & 2.75 & 1.73 & & 7 & 4.68 & 2.74 & 1.91 & & 5 & 4.68 & 2.85 & 1.83 & & 5 & 5.20 & 3.40 & 1.80 & \\
\hline & L. in & conspi & cuus & & & & tauric & & & 6 & 4.00 & 2.28 & 1.72 & & 6 & 4.97 & 3.19 & 1.78 & \\
\hline 1 & 4.66 & 2.15 & 1.74 & 0.77 & 1 & 6.06 & 2.64 & 2.22 & 1.20 & 7 & 3.33 & 1.86 & 1.47 & & 7 & 4.36 & 2.58 & 1.77 & \\
\hline 2 & 4.57 & 2.65 & 1.92 & & 2 & 5.25 & 3.43 & 1.82 & & & aph & $c a$ var & affini & & L. $a_{1}$ & haca v & ar. ps & eudoap & haca \\
\hline 3 & 4.23 & 2.74 & 1.49 & & 3 & 4.81 & 3.01 & 1.80 & & 1 & 6.77 & 3.03 & 2.49 & 1.25 & 1 & 5.53 & 2.48 & $1.90^{\prime}$ & 1.15 \\
\hline 4 & 3.97 & 2.48 & 1.49 & & 4 & 4.63 & 3.10 & 1.53 & & 2 & 5.26 & 3.52 & 1.74 & & 2 & 4.44 & 3.11 & 1.33 & \\
\hline 5 & 3.78 & 2.52 & 1.26 & & 5 & 4.30 & 2.82 & 1.48 & & 3 & 5.05 & 3.34 & 1.71 & & 3 & 4.13 & 2.69 & 1.44 & \\
\hline 6 & 3.57 & 2.20 & 1.37 & & 6 & 4.16 & 2.54 & 1.62 & & 4 & 4.87 & 3.20 & 1.67 & & 4 & 4.10 & 2.60 & 1.50 & \\
\hline 7 & 3.28 & 2.16 & 1.12 & & 7 & 3.98 & 2.39 & 1.59 & & 5 & 4.71 & 3.34 & 1.37 & & 5 & 3.90 & 2.70 & 1.20 & \\
\hline & & setifol & & & & & annu & & & 6 & 4.39 & 3.02 & 1.37 & & 6 & 3.80 & 2.51 & 1.29 & \\
\hline 1 & 7.16 & 3.34 & 2.22 & 1.60 & 1 & 8.28 & 3.42 & 3.03 & 1.83 & 7 & 4.12 & 2.71 & 1.41 & & 7 & 3.45 & 2.24 & 1.21 & \\
\hline 2 & 5.30 & 3.64 & 1.66 & & 2 & 6.44 & 4.31 & 2.13 & & & aphac & $a$ var. & modest & & & & odora & tus & \\
\hline 3 & 4.99 & 3.68 & 1.31 & & 3 & 6.14 & 4.06 & 2.08 & & 1 & 5.89 & 2.29 & 2.26 & 1.34 & 1 & 7.49 & 4.49 & 3.00 & \\
\hline 4 & 4.72 & 3.22 & 1.50 & & 4 & 6.02 & 3.79 & 2.23 & & 2 & 5.25 & 3.10 & 2.12 & & 2 & 6.66 & 4.73 & 1.93 & \\
\hline 5 & 4.36 & 2.87 & 1.49 & & 5 & 5.78 & 3.74 & 2.04 & & 3 & 4.88 & 3.13 & 1.75 & & 3 & 6.38 & 4.44 & 1.94 & \\
\hline 6 & 4.08 & 2.52 & 1.56 & & 6 & 5.54 & 3.56 & 1.98 & & 4 & 4.61 & 3.01 & 1.60 & & 4 & 6.11 & 4.07 & 2.04 & \\
\hline 7 & 3.46 & 2.02 & 1.44 & & 7 & 4.97 & 2.80 & 2.17 & & 5 & 4.40 & 2.85 & 1.55 & & 5 & 5.70 & 3.73 & 1.97 & \\
\hline & L. gorgo & ni var. & gorgor & & & & cicer & & & 6 & 4.23 & 2.61 & 1.62 & & 6 & 5.45 & 3.61 & 1.84 & \\
\hline 1 & 7.50 & 3.04 & 2.86 & 1.60 & 1 & 5.29 & 3.46 & 1.83 & & 7 & 3.95 & 2.43 & 1.52 & & 7 & 5.13 & 2.84 & 2.29 & \\
\hline 2 & 6.32 & 4.12 & 2.20 & & 2 & 4.79 & 3.07 & 1.72 & & & & & & & & & & & \\
\hline 3 & 6.08 & 4.04 & 2.04 & & 3 & 4.59 & 2.89 & 1.70 & & & & & & & & & & & \\
\hline 4 & 5.84 & 3.82 & 2.02 & & 4 & 4.39 & 2.78 & 1.61 & & & & & & & & & & & \\
\hline
\end{tabular}


chromosomal asymmetry index), and A (Degree of asymmetry). Both arm ratios were assumed to be equally affected (Adhikary 1974). All karyotype formulas were determined based on Huziwara (1962) (TF\%), Levan et al. (1964) ( $r$ and $d$ values), Zarco (1986) (A1 and A2), Watanabe (1999) (A), Peruzzi and Eroğlu (2013) (CI) as well. The abbreviations were taken from the Rezeai et al. (2014) (RLC\%, DRL, S\%). The formulas are as follows.

Formulas

$r$ value $=\frac{\text { Length of the long arm of chromosome }}{\text { Length of the short arm of chromosome }}$

$d$ value=Length of the long arm of chromosome-Length of the short arm of chromosome

arm ratio $=\frac{\text { Length of the short arm of chromosome }}{\text { Length of the long arm of chromosome }}$

$C I=\frac{\text { Length of the short arm of chromosome }}{\text { Length of the long arm of chromosome }+ \text { Length of the short arm of chromosome }}$

$R L C \%=\frac{\text { total length of each chromosome }}{\text { total length of chromosomes }} \times 100$

$D R L=($ maximum relative length $)-($ minimum relative length $)$

$T F \%=\frac{\text { total length of short arms }}{\text { total length of chromosomes }} \times 100$

$S \%=\frac{\text { length of shortest chromosome }}{\text { length of longest chromosome }} \times 100$

$A=\left(\frac{1}{n}\right) \sum A i, A i=\frac{l i-s i}{l i+s i}(l i=$ lengths of a long arm, si $=$ lengths of a short arm, $n=$ haploid chromosome number).

$A 1=1-\frac{\sum_{i=1}^{n} \frac{b_{i}}{B_{i}}}{n}(n=$ number of homologous chromosome pairs, $b_{i}=$ the average length of short arms in every homologous chromosome pair, $B_{i}=$ the average length of long arms in every homologous chromosome pair).

$A 2=\frac{s}{\bar{x}}(S=$ standard deviation of chromosome lengths, $\bar{x}$ $=$ mean of chromosome lengths).

A data matrix was constructed according to 17 karyotype characteristics mentioned in Table 3. The principal component analysis (PCA) was used based on the data matrix (Jolliffe 2002). The cluster analysis was made using Gower (dis)similarity index for determining the relationships between chromosome properties of Lathyrus taxa (Romesburg 2004). In addition, the pearson correlation coefficient ( $\mathrm{r}$ ) analysis was performed to see strong and weak relationships between chromosome properties. At the same time, Shapiro - Wilk normality test was performed. Then, the one-way analysis of variance (ANOVA) was performed to determine whether the difference between the data was statistically significant. All the analyses were carried out with PAleontoSTatistics (PAST) (Hammer et al. 2001).

\section{RESULTS}

Statistical studies on the chromosome morphologies of 26 Lathyrus taxa were conducted. Images of the mitotic metaphase chromosomes of Lathyrus taxa are given in Figure 1. Karyotype characteristics of Lathyrus taxa are given in Table 3.

The chromosome properties of taxa are summarized in the Stacked bar (Figure 2). Shapiro - Wilk normality test and One way ANOVA test results are given in Figure 3 and Table 4. According to the values obtained with the formulas using chromosome morphological properties of taxa, the data show a normal distribution (Figure 3 ), and then the one-way ANOVA test is statistically significant according to the $\mathrm{p}$-value $(\mathrm{p}<0.05)$ (Table 4$)$.

\section{Correlation analysis}

According to the correlation analysis, there are relations between the r-values of chromosome data according to the significance level less than $\mathrm{p}<0.05$. Especially a strong positive relationship between TLC, MTLC, MAX, MIN, MLA, MSA, and a strong negative relations between MRV, MDV and MAR, MCI and A1 and A values (Figure 4).

\section{Principal component analysis (PCA)}

According to PCA (Table 5, Figure 5), the first two components explained the majority of the variation according to chromosome data between the taxa. While the first two components explain 57.98 and $38 \%$ of the variance, respectively, these characters explained $96 \%$ of the total variation. The characters that affected the variation most were S\%, TLC, DRL and TF\%. Similarly, since some variables (such as A, A1) have lower values than calculations, the effects on variation in PCA have been low.

\section{Cluster analysis}

According to the UPGMA algorithm Gower index Cluster analysis results, the taxa are divided into 4 groups (Figure 6). These groups are also divided into subgroups among themselves. Especially L. hirsutus - L. odoratus, L. brachypterus var. haussknechtii - L. phaselitanus, L. stenophyllus, - L. chloranthus, L. gorgoni var. gorgoni - L. nissolia - L. pratensis, L. tuberosus - L. annuus taxa are closely related. 


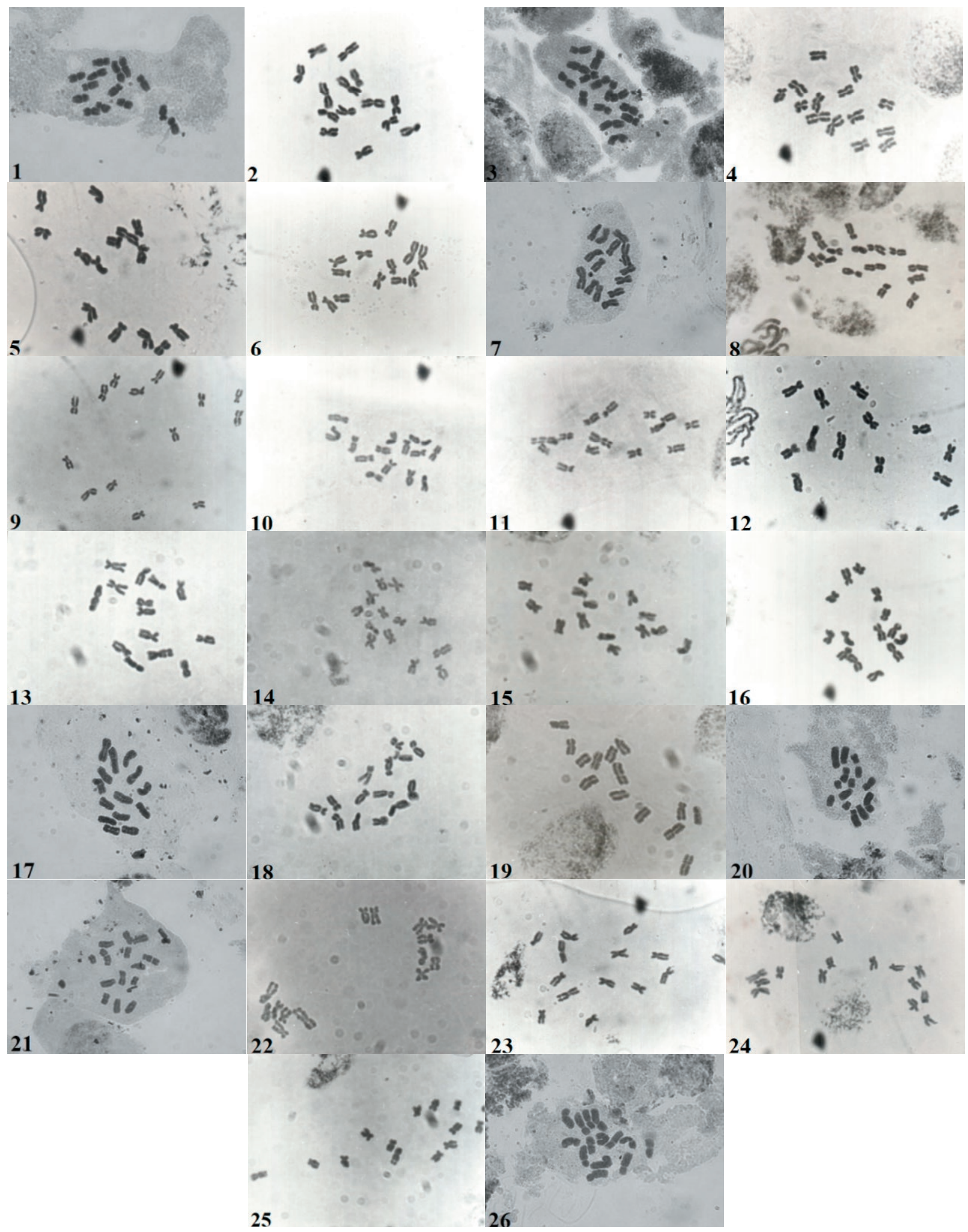

Figure 1. Mitotic metaphase chromosomes of Lathyrus taxa (1. L. brachypterus var. haussknechtii, 2. L. digitatus, 3. L. spathulatus, 4. L. pratensis, 5. L. laxiflorus subsp. laxiflorus, 6. L. tuberosus, 7. L. belinensis, 8. L. sphaericus, 9. L. inconspicuus, 10. L. tauricola, 11. L. setifolius, 12. L. annuus, 13. L. gorgoni var. gorgoni, 14. L. cicera, 15. L. sativus, 16. L. stenophyllus, 17. L. phaselitanus, 18. L. hirsutus, 19. L. chloranthus, 20. L. clymenum, 21. L. ochrus, 22. L. nissolia, 23. L. aphaca var. affinis, 24. L. aphaca var. pseudoaphaca, 25. L. aphaca var. modestus, 26. L. odoratus). 


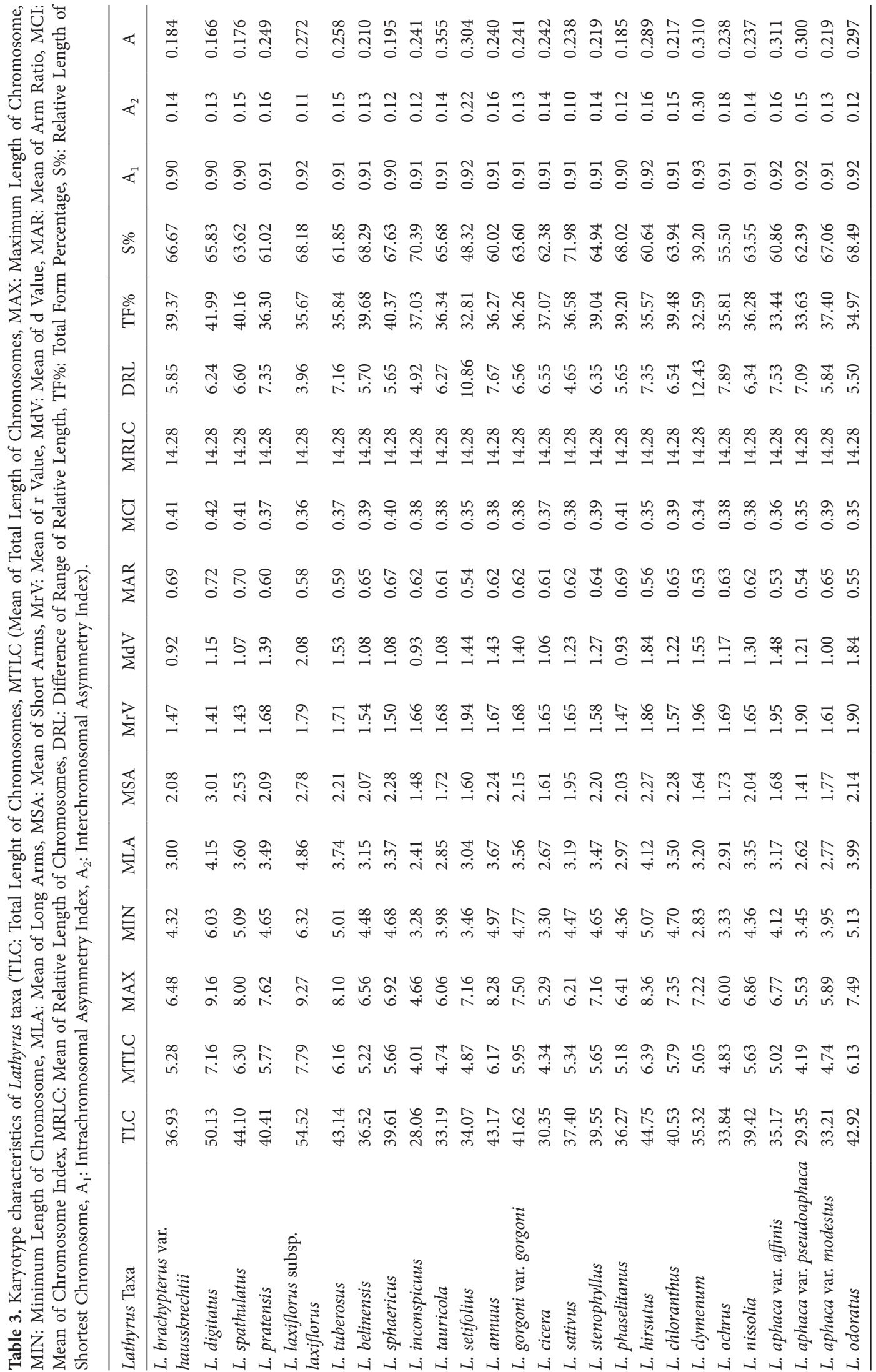




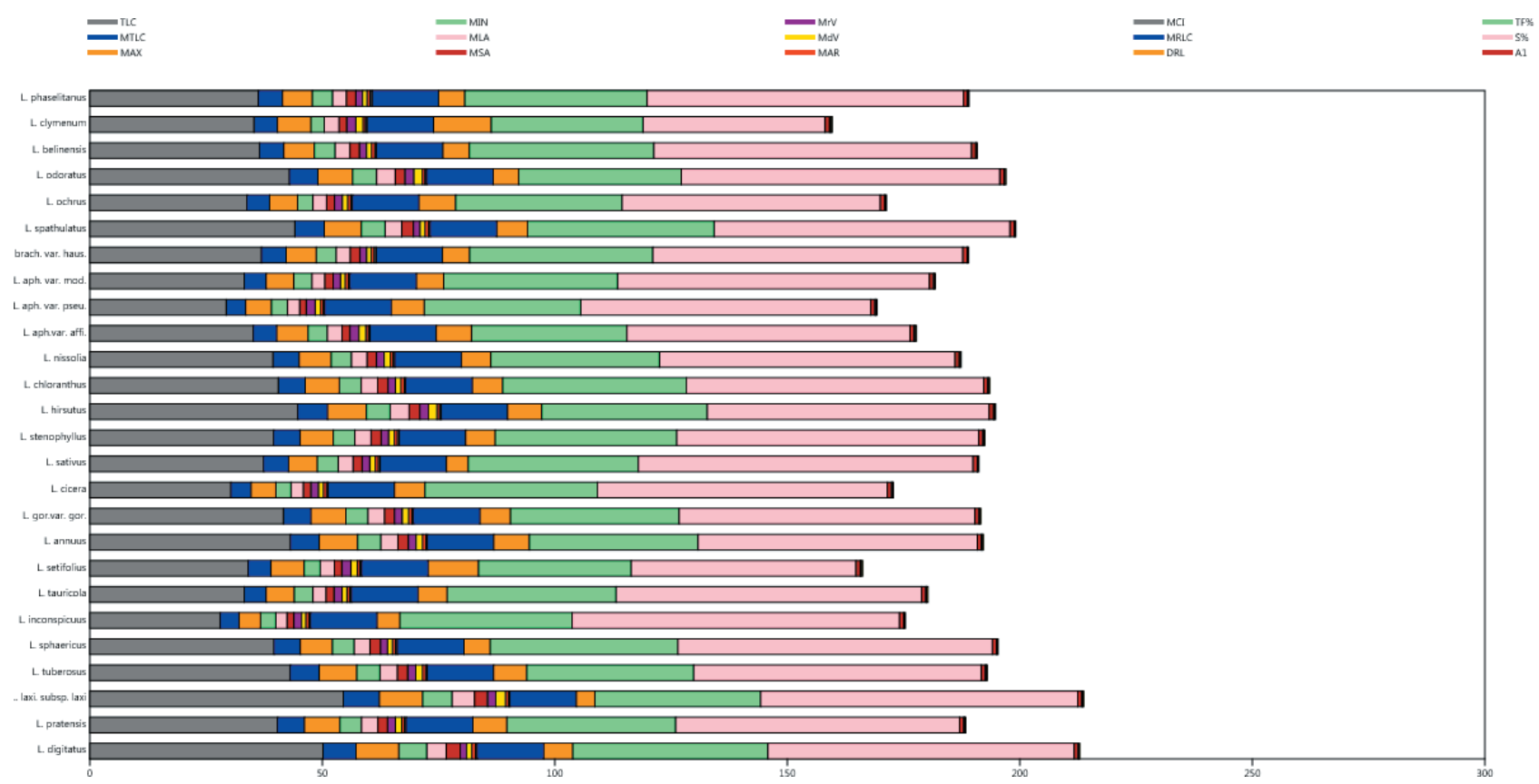

Figure 2. Lathyrus taxa karyotype characteristics of Stacked bar.

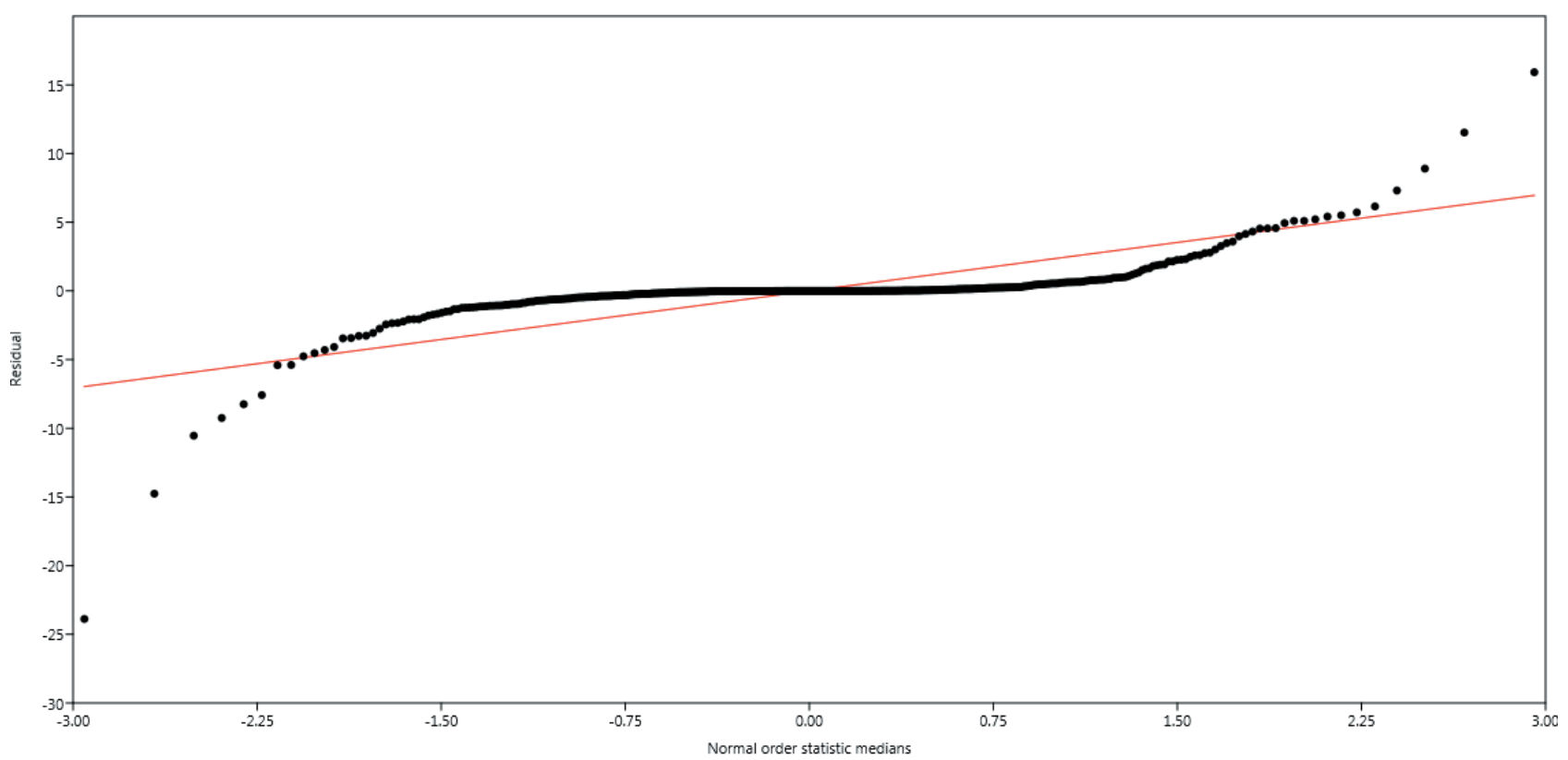

Figure 3. Shapiro - Wilk normality test.

\section{DISCUSSION}

To best of our knowledge no statistical analysis of chromosomes belonging to such a number of taxa in the genus Lathyrus is available in literature. In this study, 26 taxa belonging to 8 sections of genus Lathyrus were investigated. Among the investigated taxa, Lathyrus brachypterus var. haussknechtii, L. belinensis, L. tauricola, L. phaselitanus are endemic to Turkey.

In some studies, the cluster analysis data can yield similar trees with the morphological classification of the taxa (Açar \& Satıl 2019; Dirmenci et al. 2019). 
Table 4. One way ANOVA test results.

\begin{tabular}{lccccc}
\hline $\begin{array}{l}\text { Test for equal } \\
\text { means }\end{array}$ & $\begin{array}{c}\text { Sum of } \\
\text { sqrs }\end{array}$ & df & $\begin{array}{c}\text { Mean } \\
\text { square }\end{array}$ & $F$ & $p$ (same) \\
\hline Between groups: 133605 & 16 & 8350.28 & 1464 & $\begin{array}{c}0 \\
\text { Permutation } p \\
(\mathrm{n}=99999) \\
1 \mathrm{E}-05\end{array}$ \\
Within groups: & 2423.77 & 425 & 5.70299 & & \\
Total: & 136028 & 441 & & & \\
\hline omega $^{2}:$ & 0.9815 & & & &
\end{tabular}

Table 5. Principal component analysis of Lathyrus taxa showing the eigen values of total variance.

\begin{tabular}{lcc}
\hline PC & Eigen value & \% variance \\
\hline 1 & 56.2106 & 57.978 \\
2 & 36.8804 & 38.04 \\
3 & 3.66766 & 3.783 \\
\hline
\end{tabular}

According to the data of Doğan et al (1992), obtained in the study using forty morphological characters, the Lathyrus genus was divided into two subgenus and nine sections. However, the results obtained do not show compatibility with Davis (1970).

The statistical results obtained in our study are also not consistent with Davis (1970). This situation suggests that the statistical results obtained from taxa may not always be completely compatible with morphological features.
However, in our study, the caryological data were not generally similar to the morphological classification of the taxa, but similarities and close relationships among some taxa were also similar to morphological data (Figure 6). According to the PCA scatter diagram, like the cluster analysis results, the sections were observed to be intertwined in the distribution formations of taxa (Figure 5). Cluster analysis made according to karyotype features successfully distinguished the taxa from each other. However, it was also found to be an inconsistency with morphological classification.

According to the caryological examination, L. hirsutus - L. odoratus, L. brachypterus var. haussknechtii - L. phaselitanus, L. stenophyllus - L. chloranthus, L. gorgoni var. gorgoni - L. nissolia - L. pratensis, L. tuberosus - L. annuus taxa are closely related (Figure 6). L. hirsutus and $L$. odoratus are morphologically similar, and have been observed to be close to each other as a result of caryological analysis. L. brachypterus var. haussknechtii and L. phaselitanus differ morphologically and are located in different sections; however, these taxa are similar according to caryological data we obtained. L. stenophyllus and L. chloranthus belonging to the same section are similar to each other according to caryological analysis. And conversely, L. gorgoni var. gorgoni, L. nissolia and $L$. pratensis belonging to different sections are similar to each other according to the analysis of its metaphase chromosome morphology. Similarly, the two species, $L$. tuberosus and L. annuus from different sections are similar to each other according to cluster analysis.

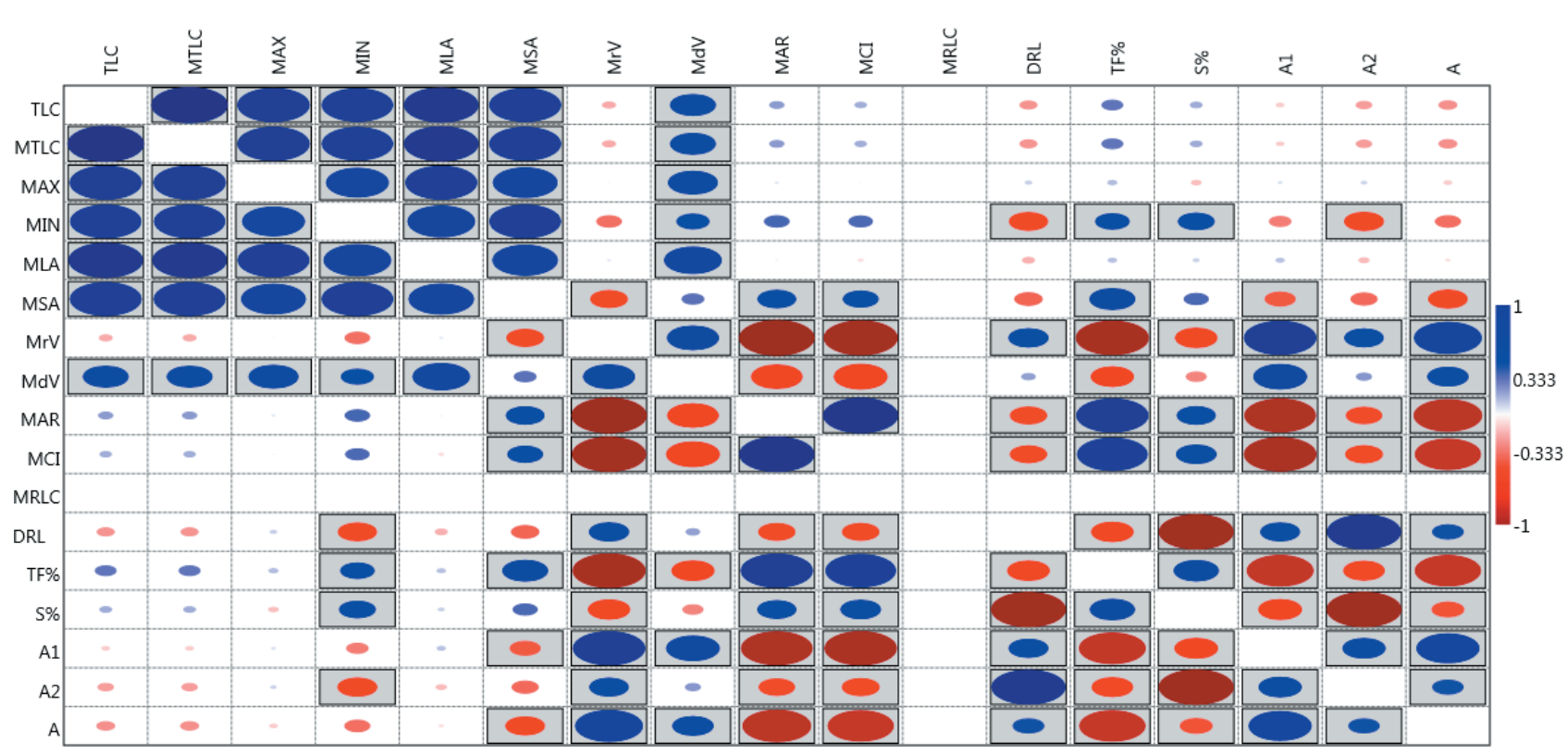

Figure 4. Correlation analysis between karyotype characteristics. 


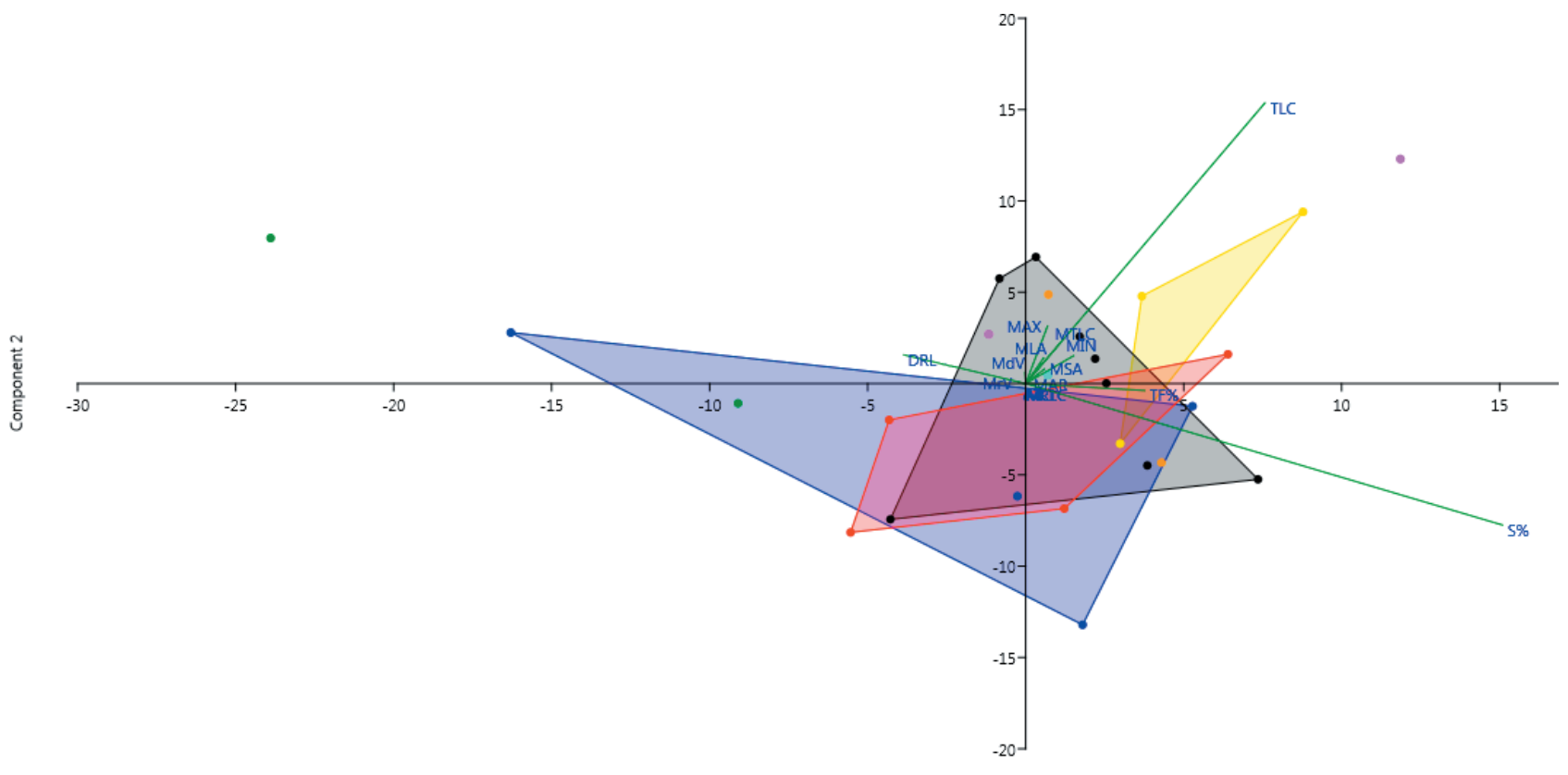

Component 1

Figure 5. PCA scatter plot diagram (Different colors refer to different sections and the lines with variables indicate the effect and direction of variation).

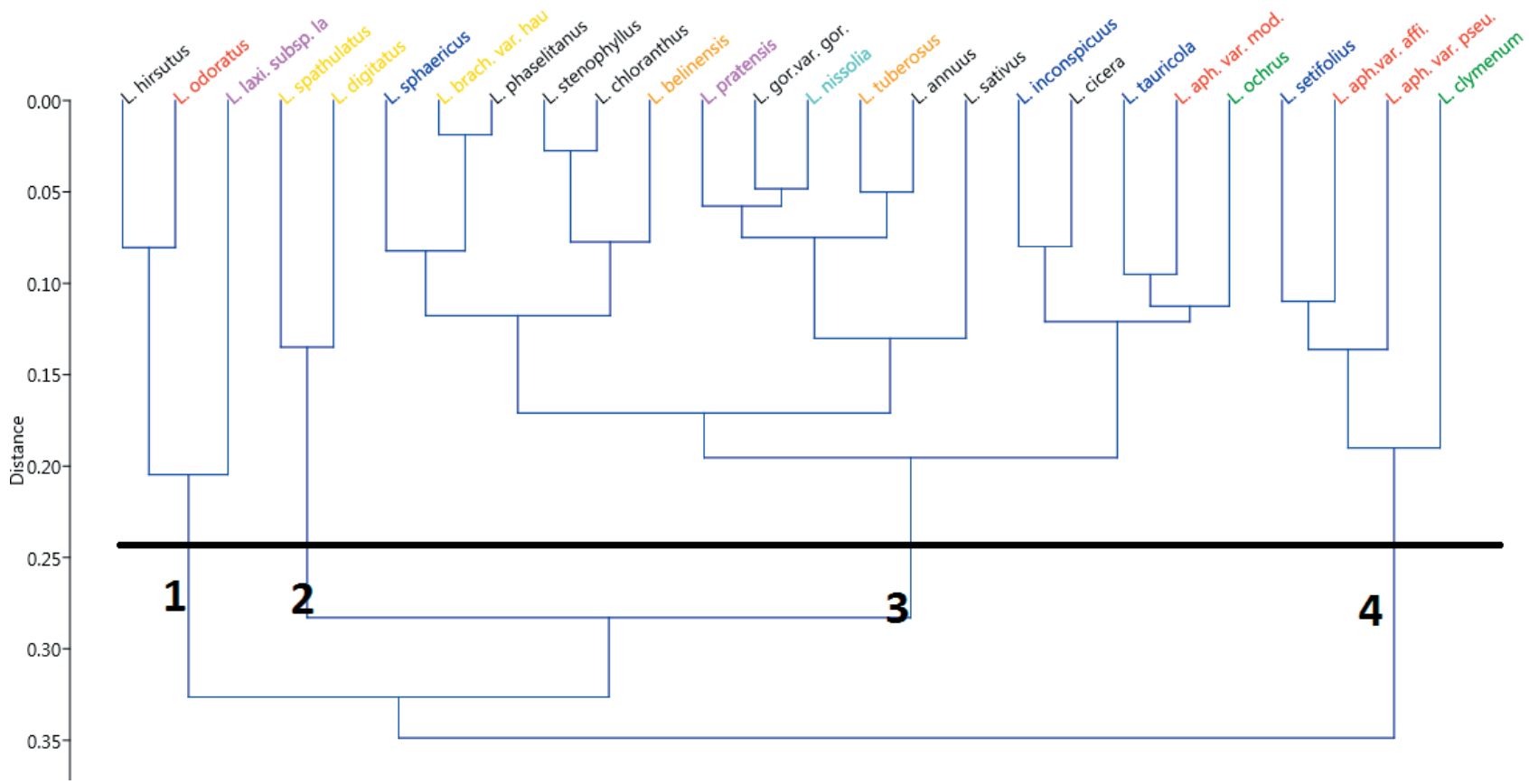

Figure 6. Cluster analysis according to karyotype characteristics (Same coloured taxa are located in the same section except L. odoratus. It is an ornamental plant).

In terms of similarities of the taxa, the presence of satellite and distribution was not found to be significant.

This study revealed that the morphological similari- ties of plant taxa and chromosomal statistics results may not be always parallel to each other. 


\section{REFERENCES}

Açar M, Satıl F. 2019. Distantes R. Bhattacharjee (Stachys L. /Lamiaceae) Altseksiyonu Taksonları Üzerinde Karşılaştırmalı Anatomik ve Mikromorfolojik Çalışmalar. Kahramanmaraş Sütçü İmam Üniversitesi Tarım ve Doğa Dergisi. 22(Ek Sayı 2): 282-295.

Adhikary AK. 1974. Precise determination of centromere location. Cytologia. 39: 11-16.

Allkin R, Goyder DJ, Bisby FA, White RJ. 1986. Names and Synonyms of Species and Subspecies in the Vicieae. Issue 3. Vicieae Database Project. Southampton: University of Southampton; 75 p.

Davis PH, Mill RR, Tan K. 1988. Flora of Turkey and the East Aegean Islands, Vol. 10 (Supplement). Edinburgh: Edinburgh University Press; 590 p.

Davis PH. 1970. Flora of Turkey and the East Aegean Islands, Vol. 3. Edinburgh: Edinburgh University Press; $627 \mathrm{p}$.

Dirmenci T, Özcan T, Açar M, Arabacı T, Yazıcı T, Martin E. 2019. A rearranged homoploid hybrid species of Origanum (Lamiaceae): O. × munzurense Kit Tan \& Sorger. Botany Letters. 166(2): 153-162.

Doğan M, Kence A, Tigın C. 1992. Numerical Taxonomic Study on Turkish Lathyrus (Leguminoseae), Edinb. J. Bot. 49(3): 333-341.

Elçi Ş. 1982. Sitogenetikte Gözlemler ve Araştırma Yöntemleri. Elazığ: Firat Üniversitesi Fen Edebiyat Fakültesi Yayınları, Uğurel Matbaası, No:3; 166 s.

Genç H, Şahin A. 2001. Batı Akdeniz ve Güney Ege Bölgesinde Yetişen Bazı Lathyrus L. Türleri Üzerinde Sitotaksonomik Araştırmalar III. Süleyman Demirel Üniversitesi Fen Bilimleri Enstitüsü Dergisi. 5(1): 98-112.

Genç H, Şahin A. 2008. A new species of Lathyrus L. (section Cicercula; Fabaceae) from Turkey. Botanical Journal of the Linnean Society. 158: 301-305.

Genç H, Şahin A. 2011. A new species of Lathyrus L. (Fabaceae) from Turkey. Journal of Systematics and Evolution. 49(5): 505-508.

Genç H, Yildirim B, Cetin T. 2009. Contribution to a karyotype analysis of some Lathyrus L. taxa (Fabaceae) in Turkey. Acta Botanica Gallica. 156(3): 455-467.

Genç H. 2009. Lathyrus nivalis subsp. sahinii subsp. nov. (Sect. Platystylis, Leguminosae) from Turkey. Nordic Journal of Botany. 27: 402-404.

Grela ER, Rybiński W, Klebaniuk R, Matras J. 2010. Morphological characteristics of some accessions of grass pea (Lathyrus sativus L.) grown in Europe and nutritional traits of their seeds. Genet Resour Crop Evol. 57(5): 693-701.

Güner A, Özhatay N, Ekim T, Başer KHC. 2000. Flora of Turkey and the East Aegean Islands, Vol. 11 (Sup- plement 2). Edinburgh: Edinburgh University Press; $656 \mathrm{p}$.

Hammer Q, Harper DAT, Ryan, PD. 2001. Past: Paleontological Statistics Software Package for Education and Data Analysis. Palaeontologia Electronica. 4(1): 1-9.

Huziwara Y. 1962. Karyotype analysis in some genera of Compositae. VIII. Further studies on the chromosome of Aster. American Journal of Botany. 49(2): 116-119.

Jolliffe IT. 2002. Principal Component Analysis. NewYork: Springer Verlag; 487 p.

Klamt A, Schifino-Wittmann MT. 2000. Karyotype morphology and evolution in some Lathyrus (Fabaceae) species of southern Brazil. Genetics and Molecular Biology. 23(2): 463-467.

Kumar J. 1997. Utilization of Lathyrus. In Mathur, P. N., Ramanatha-Rao, V., Arora, R. K. (Eds.), Lathyrus Genetic Resources Network (57-59). Proceedings of a IPGRI-ICARDA-ICAR Regional Working Group Meeting, New Delhi (India), 85 p.

Levan A, Fredga K, Sandberg AA. 1964. Nomenclature for Centromeric Position on Chromosomes. Hereditias. 52: 201-220.

Mantar N, Bağci E, Şahin A, Gür N. 2003. Lathyrus sativus L. ve L. hirsutus L. (Fabaceae/Leguminosae) türleri üzerinde morfolojik, palinolojik ve anatomik bir çalışma. Fırat Üniversitesi Fen ve Mühendislik Bilimleri Dergisi. 15(3): 303-314.

Mantar N, Genç H, Şahin A, Bağcı E. 2002. Elazı̆̆ Yöresinde Yayılış Gösteren Lathyrus inconspicuus L. ve Lathyrus vinealis Boiss. \& Noe'in Morfolojik, Anatomik ve Palinolojik Özellikleri Üzerine Bir Araştırma. Süleyman Demirel Üniversitesi Fen Bilimleri Enstitüsü Dergisi. 6(1): 159-174.

Peruzzi L, Eroğlu HE. 2013. Karyotype asymmetry: again, how to measure and what to measure? Comparative cytogenetics. 7(1): 1-9.

Rezaei M, Naghavi MR, Hoseinzadeh AH, Abbasi A, Jahangiri B. 2014. Study of Karyological Characteristics in Papaver bracteatum and Papaver somniferum. Cytologia. 79(2): 187-194.

Romesburg HC. 2004. Cluster Analysis for Researchers. North Carolina: Lulu press; 334 p.

Sharma PC, Gupta PK. 1982. Karyotypes in Some Pulse Crops. The Nucleus.25(3): 181-185.

Şahin A, Altan Y. 1990. Türkiye'nin Bazı Lathyrus L. Türleri (L.saxatilis (Vent.) Vis., L.vinealis Boiss. \& Noe, L. inconspicuus L., L.setifolius L.) Üzerinde Karyolojik Araştırmalar. Doğa Turkish Journal of Botany. 15: 50-56.

Şahin A, Genç H, Bağcı E. 1998. Cytotaxonomic Investigations on Some Lathyrus Species Growing In 
the Western Mediterranean and Southern Aegean Regions In Turkey. Acta Botanica Hungarica. 41(1-4): 229-241.

Şahin A, Genç H, Bağcı E. 2000. Cytotaxonomic Investigations on Some Lathyrus Species Growing in the Eastern Mediterranean and Southern A e g e a $\mathrm{n}$ Regions. Acta Botanica Gallica. 147(3): 243-256.

Şahin A. 1993. Türkiye’nin Bazı Lathyrus L. türleri [ $L$. rotundifolius Willd. subsp. miniatus (Bieb. ex Stev.) Davis, L. cassius Boiss., L. cicera L., L. aphaca L. var. modestus P.H. Davis]'in Karyotip Analizleri I. Doğa Turkish Journal of Botany. 17: 65-69.

Tutin TG, Heywood VH, Burges NA, Moore DM, Valentine DH, Walters SM, Webb DA. 1968. Flora Europaea, Vol. 2. Cambridge: Cambridge University Press; $469 \mathrm{p}$.

Uncuer D, Tuğay Karagül E, Niksarlı Inal F. 2017. Geçmişten Bugüne Ege'de Baklagilli Yemekler. Izmir (Turkey): Tükelmat A. Ş. Press; 89 p.

Watanabe K, Yahara T, Denda T, Kosuge K. 1999. Chromosomal evolution in the genus Brachyscome (Asteraceae, Astereae): Statistical tests regarding correlation between changes in karyotype and habit using phylogenetic information. J. Plant Res. 112: 145-161.

Yamamoto K, Fujiwara T, Blumenreich I. 1984. Karyotypes and Morphological Characteristics of Some Species in the Lathyrus L. Japan J. Breed. 34: 273-284.

Zarco RC. 1986. A new method for estimating karyotype asymmetry. Taxon. 35(3): 526-530. 